\title{
Problems and Prospects of Rice Based Cropping Patterns in Chittagong Areas
}

\author{
Jatish C Biswas $^{1 *}$ and J K Biswas ${ }^{1}$
}

\begin{abstract}
Eight districts represent Chittagong and Rangamati agricultural regions having $30637 \mathrm{sq} \mathrm{km}$ areas. These regions face natural calamities like Sidr, Aila, Resmi, salinity and soil erosion. Crops are grown in 852436 ha of land. Single crop is grown in $58.48 \%$ areas in Chittagong Hill Tracts (CHT) region, while in Chittagong agriculture region two crops are grown in about $51 \%$ areas. Rice production or its expansion is hindered because of factors like excessive or no rainfall in pre-monsoon season, soil and water salinity, water stagnation in wet season, lack of suitable rice varieties and fresh water in dry season, good income source other than farming, soil erosion, absentee farmers etc. Growing of salt tolerant varieties, organic amendments, use of cover crop, improved irrigation system can be adopted among others for land productivity improvement in coastal areas. Sorjan or ditch and pyramid or ridge systems can be utilized in coastal tidal areas. Installing subsurface drainage system and floating beds could be used in water stagnant conditions. Zero or minimum tillage following dibbling/pegging method, rain water harvesting, improved Jhum, community based seepage water harvesting, homestead gardening and floriculture are the adaptation options in hill agriculture.
\end{abstract}

Keywords: Cropping pattern, problems, prospects, Chittagong

\section{INTRODUCTION}

Eight districts (Feni, Noakhali, Laxmipur, Chittagong, Khagrachari, Rangamati, Bandarban and Cox's Bazar) belong to low productive agricultural zone in Bangladesh (Bhuiya and Mohiuddin, 2013). These diverse areas enjoy different edapho-climatic factors-char land to hilly areas, saline to nonsaline land, low to high land and water stagnant land to free flowing areas and suffer from different natural calamities like Sidr, Aila, Resmi, Mohasen, flash flood, unfavourable soil moisture regime, soil salinity, etc. Flood water recedes from about $24 \%$ areas within October, $53 \%$ in November-mid December and $23 \%$ areas in late December to early January (Sattar, 2002; Sattar and Mutsaers, 2004). In Bangladesh, about one million ha (more than $30 \%$ of cultivable area) land is in coastal areas of which T. Aman is cultivated in about 0.83 million ha (Sattar and Abedin, 2012) and about one million hectares are subjected to variable soil salinity such as very slight (2.0$\left.4.0 \mathrm{dSm}^{-1}\right)$ to very strong $\left(>15.0 \mathrm{dSm}^{-1}\right)$ as reported by Karim et al. (2010).

The hilly areas cover about $17,342 \mathrm{~km}^{2}$ (about $12 \%$ of total Bangladesh) mostly in the Chittagong Hill Tracts districts, Chittagong, Habiganj and Moulvibazar (Rahman, 2011). Chittagong Hill Tracts districts alone cover about $9 \%$ area and low hill areas (about 30\%). The high hill ranges (70\%), about $200-1,000 \mathrm{~m}$ above mean sea level), are steep to very steep hills and usually have a rather youthful soil mantle ranging from a few $\mathrm{cm}$ to several meters in thickness over bedrocks. The low hill areas $(30 \%)$, about 15 to $200 \mathrm{~m}$ above mean sea level are nearly flat or rounded topped and usually have old and deep soil. The whole hilly region receives more than $2000 \mathrm{~mm}$ precipitation annually of which about $80 \%$ is received in June-September.

${ }^{1}$ Bangladesh Rice Research Institute, Gazipur 1701. *Corresponding author's email: jatishb@yahoo.com 

Jhum (shifting cultivation following slash and burn method) is being practiced by the tribal people, especially in Chittagong hill tracts and locally in other areas. Jhum involves clearing of forest land after several years ( $4-5$ years) of fallow. However, recently fallow period has been reduced to two years due to non-availability of land. This exposure of land has increased the chance of soil erosion and further degradation of land. Annually the highest soil loss (22.68 $\left.\mathrm{t} \mathrm{ha}^{-1}\right)$ with ginger followed by turmeric (16.52 $\mathrm{t}$ ha1), aroid (12.02 $\left.\mathrm{t} \mathrm{ha}^{-1}\right)$ and Jhum rice (7.92 $\mathrm{t} / \mathrm{ha}$ ) cultivation can occurred from slope hill (Salahin et al., 2013).

Intensity of Aus, Aman and Boro rice cultivation in Chittagong areas varies depending on land suitability and availability of irrigation water along with severity of salinity. Chittagong areas have prospects of growing more rice, but it needs special care. So, we investigated the prospects and problems of rice based crop cultivation in Chittagong areas.

\section{METHODOLOGY}

Sampling technique and size: The study was conducted in Chittagong and Rangamati agriculture regions during March through July 2014. Data were collected from Feni, Noakhali, Laxmipur, Chittagong, Khagrachari, Rangamati, Bandarban and Cox's Bazar districts with the help of Deputy Director, DAE of each district and from the offices of Additional Director, DAE, Chittagong and Rangamati Agriculture Regions. Moreover, data were collected from farmers of Feni and Noakhali districts through group discussion for comparison with DAE data sources. Data have also been collected from literature review.

Analytical techniques: Collected data were edited, summarized, tabulated and analyzed to fulfil the objectives of the study. Descriptive statistics using different statistical tools like averages, percentages and ratios were used in presenting the results.

\section{RESULTS AND DISCUSSION}

\section{Chittagong agriculture region}

This agriculture region is represented by Feni, Noakhali, Laxmipur, Chittagong and Cox's Bazar districts. Saline area in southeast coastal region is 126353 , which is $8.75 \%$ of that area (Table 1). Salinity in area varies extremely within a meter to two even in the same field (Sattar and Abedin, 2012). In general, soils are slightly acidic to slightly alkaline having low organic matter content and deficient in nutrient contents (Table 2). These factors result in reduced crop yield (Table 3). Loam and clay loam soils are dominant in Chittagong agriculture region (Table 4). Sandy soil mostly prevails in Chittagong and Cox's Bazar districts. Cultivable area is $7,00,000$ ha in which two crops are grown in 356337 ha (Table 5). Single crop is grown in about $24 \%$ of cultivable land and $4.7 \%$ is current fallow. Cropping intensity is the highest in Laxmipur; however land use intensity is the highest in Feni district followed by Laxmipur district (Fig. 1). Crops are grown as intercrop/mixed crop with rice or even in the bunds (Fig. 2), on the hill top and valley (Fig.

Table 1. Stress prone areas (ha) in some selected districts of Chittagong division

\begin{tabular}{|l|c|c|c|c|c|c|c|}
\hline Type of stress & Chittagong & $\begin{array}{c}\text { Cox's } \\
\text { Bazar }\end{array}$ & Noakhali & Feni & Laxmipur & Total & $\begin{array}{c}\text { Per } \\
\text { cent }\end{array}$ \\
\hline Salinity & 20000 & 18087 & 70594 & 4000 & 13672 & 126353 & 8.75 \\
\hline Coastal & 29980 & 20800 & 140000 & 5000 & 14000 & 109781 & 7.60 \\
\hline Flood prone & 19500 & 24737 & 00 & 25000 & 60310 & 129547 & 8.97 \\
\hline Drought prone & 20000 & 19947 & 15500 & 00 & 25432 & 80879 & 5.60 \\
\hline
\end{tabular}

Source: Adopted from Ali, 2014. 

Bangladesh Rice J. 18(1\&2): 54-64, 2014

Table 2. Chemical properties of soils in selected saline belt of Bangladesh

\begin{tabular}{|l|c|c|c|c|c|c|c|c|c|c|c|}
\hline District & $\mathrm{pH}$ & $\mathrm{OM}(\%)$ & $\begin{array}{c}\text { Total N } \\
(\%)\end{array}$ & \multicolumn{1}{c|}{$\mathrm{CEC}$} & $\mathrm{Na}$ & $\mathrm{K}$ & $\mathrm{Ca}$ & $\mathrm{Mg}$ & $\begin{array}{c}\mathrm{P} \\
(\mathrm{ppm})\end{array}$ & $\begin{array}{c}\text { Zn } \\
(\mathrm{ppm})\end{array}$ \\
\hline & & & \multicolumn{7}{|c|}{$(\mathrm{m}$. e. \%) } \\
\hline Chittagong & $5.0-7.4$ & $1.0-2.9$ & - & - & - & $0.2-0.8$ & $2.7-7.1$ & $2.9-11.3$ & $4-11$ & $0.1-0.9$ \\
\hline Noakhali & $6.0-7.9$ & $0.8-3.1$ & $0.1-0.3$ & $9.4-19.5$ & $0.4-39.0$ & $0.1-0.5$ & $5.3-12.4$ & $2.3-9.5$ & $8-24$ & Tr-1.8 \\
\hline Feni & $6.0-7.5$ & $0.9-2.9$ & $0.1-0.2$ & $11.8-16.2$ & $0.8-3.8$ & $0.4-0.5$ & $7.8-8.0$ & $5.0-6.8$ & $8-24$ & Tr-0.9 \\
\hline
\end{tabular}

Sources: Annual reports of BARI, BRRI, BWDB and DU of the coordinated research project on production potentials of the coastal saline soils of Bangladesh (1987-1989).

Table 3. Crop yield loss due to different stress conditions

\begin{tabular}{|c|c|}
\hline Vulnerability & Yield loss \\
\hline \multicolumn{2}{|l|}{---- } \\
\hline Drought prone areas & 30- $60 \%$ loss in T. Aman, wheat, potato, maize, pulses, oilseeds \\
\hline $\begin{array}{l}\text { Flood- prone } \\
\text { crops }\end{array}$ & 20- $60 \%$ loss in T. Aman, Boro, wheat, maize, potato, pulses, oil seeds, spices and fruit \\
\hline $\begin{array}{l}\text { Charlands Salinity/ tidal } \\
\text { surge and Coastal Char lar }\end{array}$ & 30- $60 \%$ loss in T.Aman, Boro, wheat, maize, potato, sweet potato, pulses, oilseeds, spices \\
\hline
\end{tabular}

Source: Mia, 2011.

Table 4. Dominant soil texture in some selected districts of Chittagong agriculture zone

\begin{tabular}{|l|c|c|c|c|c|c|}
\hline \multirow{2}{*}{ Texture } & \multicolumn{7}{|c|}{ Area (ha) } & Total \\
\cline { 2 - 7 } & Chittagong & Cox's Bazar & Noakhali & Feni & Laxmipur & Tha \\
\hline Loam & 114230 & 23146 & 106227 & 46574 & 25508 & 315685 \\
\hline Clay loam & 45290 & 5100 & 95388 & 23523 & 21552 & 190853 \\
\hline Sandy loam & 33858 & 29102 & 6841 & 534 & 50118 & 120453 \\
\hline Clayey & 21655 & 18000 & 1351 & 5291 & 1250 & 47547 \\
\hline Sandy & 11412 & 14050 & 00 & 00 & 00 & 25462 \\
\hline
\end{tabular}

Source: Ali, 2014.

Table 5. Land use pattern in Chittagong areas.

\begin{tabular}{|c|c|c|c|c|c|c|}
\hline \multirow[t]{2}{*}{ Type } & \multicolumn{5}{|c|}{ Area coverage (ha) } & \multirow{2}{*}{$\begin{array}{c}\text { Total } \\
\text { (ha) }\end{array}$} \\
\hline & Chittagong & Cox's Bazar & Noakhali & Feni & Laxmipur & \\
\hline Cultivable land & 226445 & 89398 & 209807 & 75922 & 98428 & 700000 \\
\hline Net crop land & 209120 & 84312 & 202966 & 74720 & 96065 & 667183 \\
\hline Current fallow & 17325 & 5086 & 6841 & 1202 & 2363 & 32817 \\
\hline Single cropped land & 60644 & 20469 & 71179 & 9136 & 8843 & 170271 \\
\hline Double cropped land & 117654 & 49900 & 83728 & 54249 & 50806 & 356337 \\
\hline Triple cropped land & 30772 & 13943 & 48059 & 11335 & 36416 & 140525 \\
\hline More than three crops & 50 & 00 & 00 & 00 & 00 & 50 \\
\hline
\end{tabular}

Source: Ali, 2014.

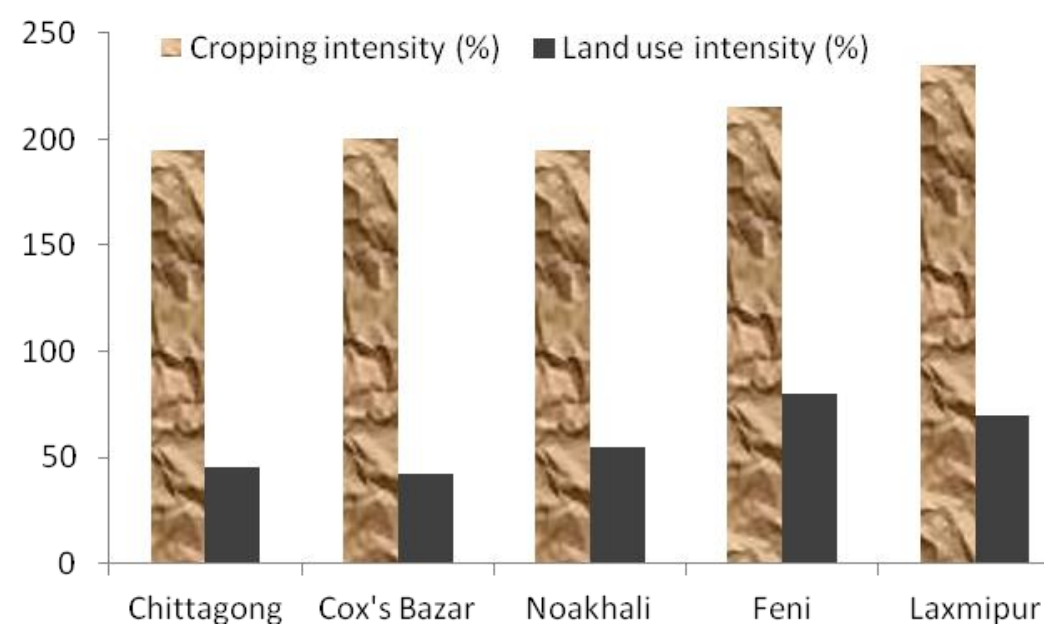

Fig. 1. Cropping and land use intensity in Chittagong areas.

Problems and Prospects of Rice Based 56 


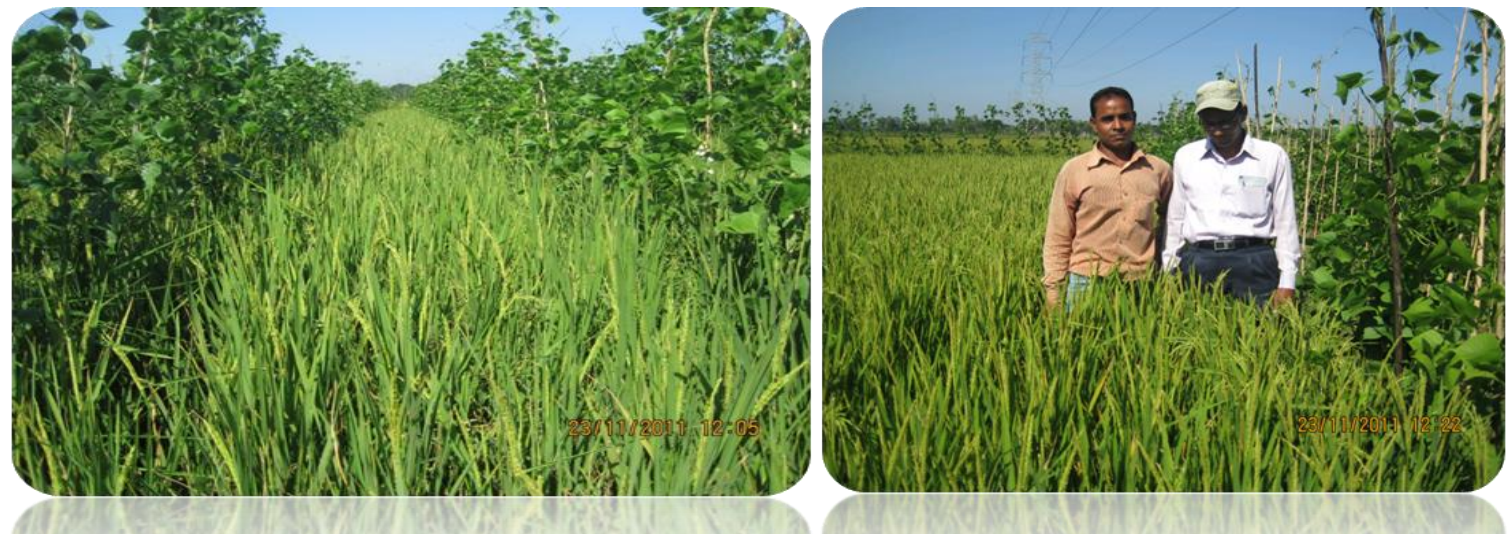

Fig. 2. Dolichos lablab (Bean) in the rice field and bunds, Chittagong (Ali, A. 2014).

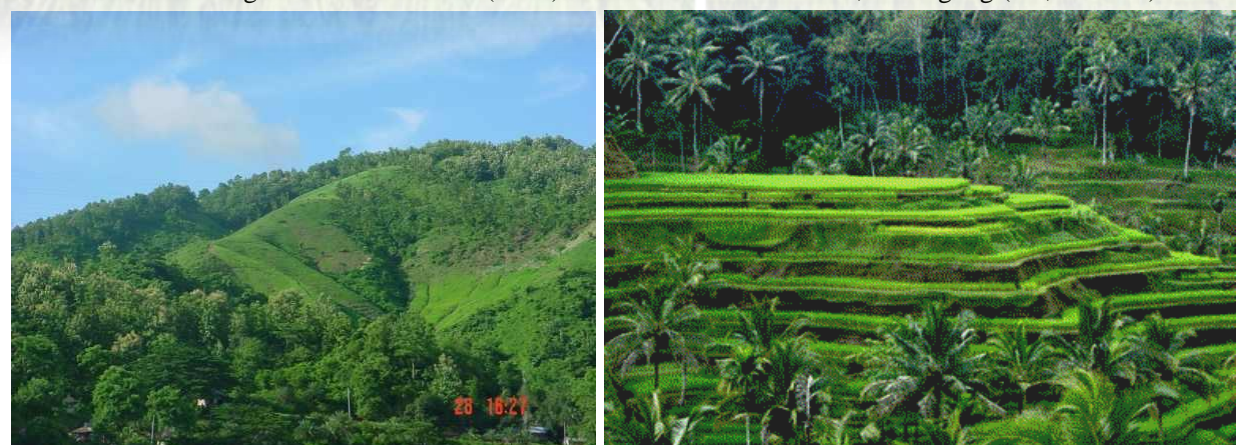

Fig. 3. Rice cultivation in hilly areas, Chittagong (Ali, 2014)

Boro-Fallow-T. Aman is the dominant cropping pattern $(26 \%)$ followed by FallowFallow-T. Aman pattern (Table 6). This implies that cropping intensity can be improved in Chittagong agriculture region by adopting suitable rice and non-rice varieties. BRRI dhan 28 is the dominant $(32 \%$ area coverage) Boro variety followed by BRRI dhan29 (Table 7). Lately released Boro rice varieties need to be introduced. MVs cover about $77 \%$ area while hybrids and local Boro varieties do the rest. Although
BRRI dhan28 has been released as Boro variety, it is the dominant variety in Aus season $(9.16 \%)$ followed by Purbachi (Table 8). Utmost effort is needed for dissemination of BRRI dhan 48 in Aus season because of its high yield potential. Local Aus rice covers about 33\% area in Chittagong agriculture region. Area coverage by BR11 is about 16\% followed by BR22 in Aman season. MVs are cultivated in $68.19 \%$ areas and the rest by local T. Aman varieties (Table 9).

Table 6. Some cropping patterns in Chittagong agriculture zone

\begin{tabular}{|l|c|c|c|c|c|c|}
\hline pattern & \multicolumn{7}{|c|}{ Area coverage (ha) } & Percent \\
\hline & Chittagong & Cox's Bazar & Noakhali & Feni & Laxmipur & \\
\hline Boro-Fallow-T. Aman & 68000 & 43000 & 16785 & 32877 & 10115 & 26 \\
\hline Fallow-Fallow-T. Aman & 50828 & 23607 & 39215 & 8966 & 00 & 18 \\
\hline Oil seeds-Aus-T. Aman & 1070 & 00 & 35609 & 748 & 23281 & 9 \\
\hline Fallow-Aus-T. Aman & 27323 & 00 & 12907 & 14944 & 500 & 8 \\
\hline Boro-Fallow-Fallow & 00 & 00 & 40766 & 00 & 3000 & 7 \\
\hline Vegetable-Aus-T. Aman & 00 & 1264 & 33821 & 00 & 1495 & 5 \\
\hline Rabi crops-Fallow-T. Aman & 10426 & 4216 & 00 & 5978 & 3292 & 5 \\
\hline Pulses-Fallow-T. Aman & 6084 & 00 & 19787 & 00 & 00 & 4 \\
\hline Pulses-Aus-T. Aman & 9124 & 00 & 00 & 6725 & 3150 & 2.8 \\
\hline Oilseeds-Fallow-T. Aman & 00 & 00 & 00 & 00 & 18685 & 2.8 \\
\hline Vegetable-Vegetable-T. Aman & 2682 & 843 & 00 & 2989 & 00 & 1 \\
\hline Boro-Aus-T. Aman & 1230 & 843 & 00 & 00 & 5500 & 1 \\
\hline Tuber crops-Aus-T. Aman & 6043 & 00 & 00 & 751 & 00 & 1 \\
\hline
\end{tabular}

Source: Ali, 2014.

57 Biswas \& Biswas 

Bangladesh Rice J. 18(1\&2): 54-64, 2014

Table 7. Area coverage (ha) by dominant Boro rice varieties in Chittagong areas.

\begin{tabular}{|l|c|c|c|c|c|c|c|}
\hline Variety & Chittagong & Cox's Bazar & Noakhali & Feni & Laxmipur & Total & Percent \\
\hline Hira1-6 & 1800 & 2478 & 16335 & 727 & 1215 & 22555 & 10.0 \\
\hline ACI-1 & 534 & 205 & 3719 & 405 & 841 & 5704 & 2.5 \\
\hline BADC & 2061 & 1073 & 400 & 463 & 00 & 3997 & 1.8 \\
\hline All hybrids & 6403 & 8322 & 32100 & 2175 & 3566 & 52566 & 23.0 \\
\hline BRRI dhan28 & 23588 & 20415 & 4828 & 13031 & 11533 & 73395 & 32.0 \\
\hline BRRI dhan29 & 6870 & 4591 & 6960 & 10419 & 7713 & 36553 & 16.0 \\
\hline BR16 & 5175 & 2755 & 5961 & 1680 & 1178 & 16749 & 7.4 \\
\hline BRRI dhan33 & 2734 & 3235 & 00 & 00 & 00 & 5969 & 2.6 \\
\hline BRRI dhan47 & 1888 & 3060 & 75 & 250 & 306 & 5579 & 2.5 \\
\hline All MVs & 54547 & 44856 & 21845 & 27897 & 25052 & 174197 & 76.7 \\
\hline All local & 00 & 649 & 00 & 00 & 52 & 701 & 0.3 \\
\hline
\end{tabular}

Source: Adopted from Ali, 2014.

Table 8. Area coverage (ha) by dominant Aus rice varieties in Chittagong areas.

\begin{tabular}{|l|c|c|c|c|c|c|c|}
\hline Variety & Chittagong & Cox's Bazar & Noakhali & Feni & Laxmipur & Total & Percent \\
\hline All hybrids & 3845 & 00 & 00 & 40 & 00 & 3885 & 2.55 \\
\hline BRRI dhan28 & 3123 & 3245 & 3270 & 4052 & 275 & 13965 & 9.16 \\
\hline Purbachi & 3735 & 00 & 00 & 2789 & 6240 & 12764 & 8.38 \\
\hline BRRI dhan27 & 1999 & 403 & 5190 & 906 & 2110 & 10608 & 6.96 \\
\hline BR26 & 3836 & 169 & 2363 & 395 & 1277 & 8040 & 5.28 \\
\hline BRRI dhan43 & 1479 & 60 & 6280 & 15 & 158 & 7992 & 5.24 \\
\hline BR14 & 2934 & 00 & 1560 & 650 & 805 & 5949 & 3.90 \\
\hline BR16 & 2084 & 188 & 2870 & 160 & 548 & 5850 & 3.84 \\
\hline BR20 & 2700 & 00 & 2367 & 00 & 193 & 5260 & 3.45 \\
\hline BRRI dhan42 & 2053 & 425 & 2255 & 00 & 40 & 4773 & 3.13 \\
\hline BR21 & 505 & 45 & 3610 & 130 & 295 & 4585 & 3.01 \\
\hline All MVs & 34039 & 6260 & 31200 & 12164 & 14060 & 97723 & 64.10 \\
\hline Shaita & 00 & 00 & 11930 & 300 & 6855 & 19085 & 12.50 \\
\hline Boilam & 3545 & 00 & 6840 & 00 & 813 & 11198 & 7.35 \\
\hline All local Aus & 8580 & 70 & 27150 & 4446 & 10530 & 50776 & 33.30 \\
\hline
\end{tabular}

Source: Adopted from Ali, 2014.

Table 9. Area coverage (ha) by dominant T. Aman rice varieties in Chittagong areas.

\begin{tabular}{|l|c|c|c|c|c|c|c|}
\hline Variety & Chittagong & Cox's Bazar & Noakhali & Feni & Laxmipur & Total & Percent \\
\hline BR11 & 22308 & 12647 & 4508 & 13914 & 9204 & 62581 & 16.40 \\
\hline BR22 & 26509 & 3430 & 4666 & 11263 & 5963 & 51831 & 13.60 \\
\hline BRRI dhan40 & 7420 & 2439 & 19125 & 3728 & 9024 & 41736 & 11.00 \\
\hline Pajam & 28027 & 7569 & 00 & 793 & 96 & 36485 & 9.58 \\
\hline BRR dhan41 & 7577 & 2504 & 8163 & 4830 & 6545 & 29619 & 7.78 \\
\hline BR23 & 6085 & 1133 & 10609 & 4067 & 7161 & 29055 & 7.63 \\
\hline BRRI dhan32 & 9110 & 7141 & 600 & 2971 & 4794 & 24616 & 6.47 \\
\hline BRRI dhan49 & 9965 & 3460 & 631 & 2780 & 1402 & 18238 & 4.79 \\
\hline BR10 & 6587 & 6405 & 114 & 875 & 562 & 14543 & 3.82 \\
\hline BRRI dhan33 & 3150 & 10304 & 165 & 00 & 13 & 13632 & 3.58 \\
\hline All MVs & 147185 & 69140 & 53342 & 59450 & 51595 & 380712 & 68.19 \\
\hline Kajalshail & 800 & 00 & 38790 & 1855 & 9518 & 50963 & 9.13 \\
\hline Rjashail & 10665 & 00 & 20240 & 855 & 2997 & 34757 & 6.23 \\
\hline Ghigaj & 00 & 00 & 10150 & 431 & 2270 & 12851 & 2.30 \\
\hline All local T. Aman & 32320 & 7210 & 103200 & 8185 & 26685 & 177600 & 31.81 \\
\hline
\end{tabular}





\section{Chittagong Hill Tracts agriculture region}

Chittagong Hill Tracts (CHT), consisting of Bandarban, Khagrachari, and Rangamati districts is situated in the south-east of Bangladesh. Area of this region is 13,295 sq. $\mathrm{km}$. It is marked by chains of hills running from the south to north-west and deep valleys formed by the rivers of Feni, Karnafuli, Sangu and Matamuhuri and their tributaries. The rivers are subject to severe flash floods if heavy rainfall occurs during monsoon. Alternative hills and valleys are covered with forests, bushes and other vegetation. The relative reliefs are about 457 to 884 meters above sea level in the south and 305 to $610 \mathrm{~m}$ in the north. The Chengi, the Myani and the Kassalong valies in the north are flat and fertile land in the region. Average precipitation is $2700 \mathrm{~mm}$. However annual rainfall varies from 1836 to $3043 \mathrm{~mm}$. Maximum temperature ranges between $30^{\circ}$ to $37^{\circ} \mathrm{C}$ and minimum from $12^{\circ}$ to $21^{\circ} \mathrm{C}$. Soils are mostly clay loam, sandy loam and silty clays. Silty clay loam is the dominant texture, which covers $67 \%$ of the total area. The hill soils are mainly yellowish brown having one to four feet depth.

There are 1,52,436 ha total cultivable land in CHT, in which single cropped area is dominant (Table 10). Efforts are needed to convert these lands to double or even triple cropped areas. A large area $(67,191 \mathrm{ha})$ remains fallow, might be due to lack of irrigation facilities. Cropping intensity is only $140 \%$. Hybrid rice covers 7,110 ha in Boro season (Table 11), Hira being the dominant variety ( $40 \%$ of hybrid area). BRRI dhan28 is dominant variety followed by BRRI dhan29. Local cultivar Gelong and Binni is dominant in Aus season- Gelong is dominant followed by Bini (Table 12). BR11 is dominant in T. Aman season followed by BRRI dhan33 (Table 13). Local T. Aman cultivar covers about $5 \%$ area in Aman season.

Table 10. General land use pattern in Chittagong Hill Tracts agriculture region

\begin{tabular}{|l|c|c|c|c|}
\hline Item & Rangamati & Khagrachari & Bandarban & Total \\
\hline Total cultivable land (ha) & 56208 & 41833 & 54395 & 152436 \\
\hline Single cropped area (ha) & 35630 & 24587 & 28930 & 89147 \\
\hline Double cropped area (ha) & 11738 & 24587 & 15478 & 51803 \\
\hline Triple cropped area (ha) & 1874 & 13380 & 3172 & 18426 \\
\hline Current fallow & 34496 & 25880 & 6815 & 67191 \\
\hline Total cropped area & 81746 & 62945 & 69402 & 214093 \\
\hline Cropping intensity (\%) & 123 & 150 & 146 & 140 \\
\hline Forest area (ha) & 469872 & 146058 & 273050 & 888980 \\
\hline Irrigated land (ha) & 6510 & 13500 & 6457 & 26467 \\
\hline
\end{tabular}

Source: Ali, 2014.

Table 11. Area coverage (ha) of Boro rice in Chittagong Hill Tracts agriculture region

\begin{tabular}{|l|c|c|c|c|}
\hline Variety & Rangamati & Khagrachari & Bandarban & Total \\
\hline Hira & 1137 & 1020 & 692 & 2849 \\
\hline ACI & 379 & 352 & 283 & 1014 \\
\hline Rajkumar & 233 & 46 & - & 279 \\
\hline Gold & 105 & - & 33 & 138 \\
\hline All hybrids & 2700 & 2867 & 1543 & 7110 \\
\hline \multicolumn{5}{|c|}{ Modern variety } \\
\hline BRRI dhan28 & 2255 & 2642 & 1845 & 6742 \\
\hline BRRI dhan29 & 625 & 2199 & 491 & 3315 \\
\hline BR16 & 311 & 290 & 444 & 1045 \\
\hline Purbachi & 221 & 259 & - & 480 \\
\hline BR10 & 195 & - & 55 & 250 \\
\hline BRRI dhan50 & 181 & 181 & 20 & 382 \\
\hline All MVs & 4195 & 8010 & 4720 & 16925 \\
\hline Bini & 0 & 0 & 37 & 37 \\
\hline All Boro rice & 6895 & 10877 & 6300 & 24397 \\
\hline
\end{tabular}

Source: Ali, 2014. 

Bangladesh Rice J. 18(1\&2): 54-64, 2014

Table 12. Aus area (ha) coverage in CHT agriculture region

\begin{tabular}{|c|c|c|c|c|}
\hline Variety & Rangamati & Khagrachari & Bandarban & Total \\
\hline \multicolumn{5}{|c|}{ Hybrid } \\
\hline Hira & - & - & 408 & 408 \\
\hline $\mathrm{ACI}$ & - & - & 243 & 243 \\
\hline All hybrids & - & - & 786 & 786 \\
\hline \multicolumn{5}{|c|}{ Modern variety } \\
\hline BR1 & 204 & 80 & - & 284 \\
\hline Purbachi & 197 & 301 & 153 & 651 \\
\hline BR26 & 135 & 448 & 157 & 740 \\
\hline BRRI dhan27 & 133 & 132 & 133 & 398 \\
\hline BR24 & 124 & 76 & 3 & 203 \\
\hline All MV Aus & 1090 & 2772 & 2841 & 6703 \\
\hline \multicolumn{5}{|c|}{ Local Aus } \\
\hline Gelong & 1284 & 380 & 1171 & 2835 \\
\hline Bini & 538 & 137 & 1294 & 1969 \\
\hline Kockra & 0 & 0 & 1137 & 1137 \\
\hline Pidi & 0 & 0 & 912 & 912 \\
\hline Kobrak & 832 & 46 & - & 878 \\
\hline Chakachikan & 0 & 0 & 808 & 808 \\
\hline Badoia & 431 & 69 & - & 500 \\
\hline Kamarang & 415 & 50 & 0 & 465 \\
\hline All local Aus & 4760 & 1484 & 8990 & 15234 \\
\hline All Aus & 5850 & 4256 & 12617 & 22723 \\
\hline
\end{tabular}

Source: Ali, 2014.

Table 13. Area coverage (ha) of T. Aman rice in Chittagong Hill Tracts agriculture region

\begin{tabular}{|c|c|c|c|c|}
\hline Variety & Rangamati & Khagrachari & Bandarban & Total \\
\hline \multicolumn{5}{|c|}{$H Y V$} \\
\hline BR11 & 2404 & 9188 & 2935 & 14527 \\
\hline BRRI dhan33 & 57 & 2902 & 1432 & 4391 \\
\hline Pajam & 2228 & 491 & 1118 & 3837 \\
\hline BR10 & 1097 & 1155 & 1356 & 3608 \\
\hline BRRI dhan 40 & 527 & 2306 & 676 & 3509 \\
\hline BRRI dhan39 & 510 & 1909 & 373 & 2792 \\
\hline BRRI dhan41 & 314 & 1919 & 455 & 2688 \\
\hline BRRI dhan49 & 548 & 1743 & 270 & 2561 \\
\hline All MVs & 9719 & 25240 & 11520 & 46479 \\
\hline \multicolumn{5}{|c|}{ Local T. Aman } \\
\hline Bini & 225 & 349 & 140 & 714 \\
\hline Sonali Pajam & - & 513 & - & 513 \\
\hline Kalijira & 32 & 403 & 5 & 440 \\
\hline All local T. Aman & 351 & 2089 & 286 & 2538 \\
\hline All T. Aman & 10070 & 27329 & 11806 & 49205 \\
\hline
\end{tabular}

Source: Ali, 2014.

\section{PROBLEMS WITH RICE CULTIVATION}

\section{Aus rice}

- Excessive or no rainfall in April

- Salinity, especially 60,000 ha in char areas

- Inadequate turnaround time after groundnut (100\% area) and soybean (50\% area) harvest in char areas

- Farmers are reluctant to cultivate Aus rice because of probable flash flood in Porshuram,

- Fulgazi and Chhagalnaiya upazilas
- Water stagnation

T. Aman rice

- Water stagnation (3-4 ft) in Chatkhil, Sonaimuri, Begungang and partial areas of Noakhali sadar, Senbug and Kabirhat

- Lack of suitable variety

\section{Boro rice}

- Inadequate irrigation facilities

- Salinity

- Inadequate availabilty of salt tolerant varieties

Problems and Prospects of Rice Based 60 



\section{Jhum rice}

- Continuous soil and nutrient loss in hill soils, which is accelerated by open cultivation system on steep to very steep land

- Soils are very acidic and require relatively heavy use of fertilizer for sustainable agricultural production

- Lack of suitable varieties and/or dissemination activities

- Language problem for communication in Chittagong Hill Tracts region

- Water scarcity during Aus and Boro season

- Sand deposition in crop land after heavy rainfall

- Improper Jhum cultivation

\section{General problem for rice cultivation}

- Inadequate quality seed and/dissemination activities

- Sandy soil in Chittagong and Cox's Bazar areas

- Shrimp cultivation in Chittagong and Cox's Bazar areas

- Absentee farmers

- Earnings of foregin currencies- better livelihood than rice farmers

- Lack of technical knowledge

\section{SUGGESTIONS FOR SOLUTIONS OF} PROBLEMS

\section{Coastal agriculture}

- There exist elevation differences in certain parts of coastal areas having standing water depth of $15-90 \mathrm{~cm}$ where BRRI dhan40, BRRI dhan41, BRRI dhan53 and BRRI dhan54 can be cultivated in T. Aman season. Felon can be relayed with T. Aman.

- Rain water harvesting reservoirs can be constructed for supplemental irrigation in wet season and for growing dry season crops.

- Keeping land covered in winter and summer months. Ground water is saline and present at a shallow depth (about 1.0 meter). Keeping lands fallow leads to high salinity in soil due to evaporation of excessive soil moisture. Therefore, it is recommended to avoid fallowing of lands during dry season. Salt tolerant crops should be grown. This will lower the profile salinity.

- Growing salt tolerant crops like BRRI dhan47, BARI Tishi, Sunflower, etc. BARI Tishi can tolerate up to $16 \mathrm{dS} \mathrm{m}^{-1}$ salinity.

- Land should be properly levelled to prevent accumulation of water in the low-lying patches with shallow ground water tables and to facilitate uniform drainage of excess water. It will help to apply irrigation water uniformly in dry season, facilitate uniform germination of seeds and better growth of crops.

- Organic matter build up in tropical environment is very difficult because of its rapid decomposition rate. So, organic matter addition annually provides beneficial effects for growing crops in coastal belt. For example, use of organic materials like Sesbania, Lathyrus sativas (L.) and red clover (Melilotus alba, L.) is beneficial for higher grain yield of rice in coastal flooded soil (Islam et al., 2010). Shah et al. (2004) also reported higher grain yield of rice with additional potassium and ash application compared to soil test based fertilizer management in coastal areas of Bangladesh

- Provision of sub-surface drainage. In many parts of the coastal area, salinity is very high. To grow crops successfully in those areas, it is necessary to bring down the salinity by leaching the salts. It is also necessary to lower down the water table and maintain it blow the critical depth to prevent salt effect on crops grown. To achieve the objective, a proper subsurface drainage has to be installed to keep the ground water at least one meter below the soil surface. This technology is effective but somewhat expensive.

- Improved irrigation technique along with improved land preparation helps in growing crops successfully in saline areas (Islam and Rashid, 2011).

- Sorjan or ditch system can be followed for growing crops in coastal tidal areas.

- Pyramid/ridge cropping system can be utilized for crop cultivation in saline areas (Sattar and Abedin, 2012). The height of pyramid will depend on the depth of water in Kharif season. 

- Use of drought tolerant or escaping crops (eg Felon, Lentil, etc) and use of mulch for moisture preservation (Ali, 2014).

- Dibbling method of crop establishment. The advantage of this system is to escape the detrimental effects of surface soil salinity during germination and seedling growth.

- Protective embankment having sluice gates. Land may be protected from inundation of saline water through establishment of embankment of suitable size. The recommended size should be one meter high above the high tide level. Excess water can be removed and intrusion of saline water during high tide can be controlled through proper sluice gate operation.

\section{Stagnant water areas}

- Ways to improve drainage. In the long term, some options like re-shaping the layout of the field, improving surface drainage, installing subsurface drainage could be considered to improve drainage of the affected fields. Underground drainage systems including conventional mole and gravel mole systems, in combination with surface drainage, also have the potential to significantly increase grain production in many of the areas prone to waterlogging (Johnston, 1999)

- Vegetable can also be grown in raise beds or even in floating beds (www.coastalcooperation.net). Floating beds are made of water hyacinth, deep water rice straw and different types of aquatic vegetations like Lemna trisulca, Azolla pinnata and Bluxa japonica and bamboo poles (Practical Action: www.practicalaction.org). Initially farmers lay a bamboo pole on dense water hyacinth to stand on and then pile more water hyacinth to make it compact. The thickness depends on the duration of water logging, as it needs to float for the whole time of inundation. The bed is movable so the farmer can choose suitable locations for better management. After selecting a good location, the beds are usually fixed with bamboo poles.
After 10-15 days, the farmers may transplant seedlings or broadcast vegetable seeds. More than 20 vegetable varieties like red amaranth, Indian spinach, coriander leaves, cauliflower, cabbage, tomato, lady's finger, cucumber, bitter gourd, bottle gourd, snake gourd, ash gourd, sweet pumpkin, bean, radish, eggplant, potato, chilli, onion, garlic, turmeric and mustard are grown on floating beds in different locations of Bangladesh (www.coastalcooperation.net/part-III).

- In certain areas, delay in Boro harvesting or early floods after Boro crop delays or no scope of deepwater rice crop planting. Integration of Boro-deepwater rice farming is needed for such type of areas. Direct seeding (45 kg ha-1) of sprouted seeds of deepwater rice in a standing crop of Boro rice (which is usually a transplant crop) 15 day before the harvesting of Boro rice is one of the possibilities (Abedin and Bool, 2004). Transplanting of 30-60 day-old deep water rice seedlings after Boro harvest (Hossain and Haque, 1987) is another option of crop intensification.

\section{Hill area problems}

- More than $60 \%$ farmers had no formal education in hilly areas (www.bioscienceassociates.com/2013/04/survey-ofcropping-and-livelihood-in.html). So, a hand on training on modern cultivation is essential. Fallow-Fallow-T. Aman is the dominant pattern, which needs to be converted to double or triple cropped areas. Mia (2011) reported that innovative practices like agro-forestry farming, zero or minimum tillage following dibbling/pegging method (ginger, turmeric, maize, tomato), rain water harvesting, improved Jhum, community based seepage water harvesting, homestead gardening, floriculture, etc, are the adaptation options in hill agriculture.

- In the drought-prone areas, fallow lands after T. Aman might be used for growing crops with zero tillage (Maize), mulching (Potato), priming (Chickpea) and dry

Problems and Prospects of Rice Based 62 

land farming, cultivation of sesame (Mia, 2009).

- High water table indicator flora eg wild banana, ferns, zinzibers, canes and bamboos etc. should be re-established. Right plant (crop) at right place according to their habit and habitat is needed be cultured.

- Post harvest management of crops like jackfruit, citrus and lemons, litchi, Kao (Garcinia) and pineapple etc, and vegetables are needed to get better price by the growers.

- Farmers should be made aware of and encouraged to adopt improved agricultural practices and soil conservation measures to enhance productivity:

- An improved Jhum can be created by selectively weeding the fields and enriching them by planting species that increase the rate of return of organic matter to the soil and have some commercial interest for the farmer (such as commercial bamboos and various leguminous shrubs).

- Use of mulch prevents soil degradation and excessive weed emergence. This technique can be used by farmers for growing ginger and taro in hilly areas of this region.

- Contour plantation is a common practice in the Hill Tracts which facilitate soil erosion with the onset of heavy rains. Existing system needs to be modified by cultivating plants along the contours to prevent soil loss.

- Use of cover crops and use of strip cropping: Row crops such as rice, tobacco, maize etc are not effective as soil conserving crops. Using legumes in the existing cropping system will provide better cover and protection to soil by way of minimizing the impact of raindrop erosion and acting as an obstruction to runoff.

- Crop diversification: Crop diversification from low value to high value crops; from water loving crop to water saving crop and from single crop to multiple/mixed crop can provide adequate income and employment to the farmers.

\section{CONCLUSIONS}

Chittagong area belongs to low agricultural productive zone in which two crops are generally grown in about $51 \%$ areas. Expansion of rice production is limited because of either excessive or no water for its cultivation, soil erosion and lack of salt tolerant along with many other bottlenecks. Introduction of drought and salt tolerant varieties, pyramid or ridge methods of crop establishment, rain water harvesting, organic amendments and improved Jhum system can be adopted in hill agriculture.

\section{REFERENCES}

Abedin M Z, M R L Bool. 2004. Relay cropping of boro rice-deepwater rice, pages 1-6 in Agricultural technologies for rural poverty alleviation. Technical Advisory Notes. Flood-prone Rice Farming Systems Series. Los Baños (Philippines): International Rice Research Institute and International Fund for Agricultural Development. p. 57.

Ali, M A. 2014. Cultivation of Aus and Aman rice in Chittagong areas. Paper presented at BRRI-DAE workshop, BRRI, Gazipur.

BBS (Bangladesh Bureau of Statistics). 1993. Statistical Year Book of Bangladesh, 1992. Dhaka.

Bhuiya, M M R and H Mahiuddin. 2013. Agricultural regionalization of Bangladesh based on productivity and analysis of spatial dependencies of for productivity between the districts of Bangladesh. J. Bangladesh Inst. Planners, 6: 181189.

Hossain, M M and M Z Haque. 1987. Seedling age and density effects on basal tiller survival and yield of transplanted deepwater rice. Proceedings of the 1987 International Deepwater Rice Workshop. pp. 455-456.

Islam, M S and M H Rashid. 2011. Climate change and sustainable irrigation management in Bangladesh. In: R Lal, M K V Sivkumar, S M A Faiz, A H M M Rahmanm and K R Islam (ed.) Climate Change and Food Security in South Asia. Springer Dordrht pages, pp. 407-421.

Karim, Z, N K Saha, S Hussain and Z Abedin. 2010. Climate change dynamics and Bangladesh Agriculture. Consultancy report submitted to IRRI, 2010.

Mia, M M U. 2011. Adaptation practices for crop production in climate change vulnerable areas in Bangladesh. Tech Bull No. 12, 2011. Krishi Gobeshona Foundation, BARC Complex, Dhaka.

Rahman, M A. 2011. Biodiversity Conservation and Food Security of Indigenous People Hilly Regions of Bangladesh (Access at http://feppcar.org/150/ biodiversity-conservation-and-food-security-ofindigenous-people-hilly-regions-of-bangladesh/ on 15-4-2014).

Salahin N, R A Begum, S Hossian, M M Ullah and M K Alam. 2013. Degradation of soil properties under Ginger, Turmeric, Aroid and Jhum rice cultivation 

in hilly areas Of Bangladesh. Bangladesh J. Agril. Res. 38(2): 363-371

Sattar, S A and M Z Abedin. 2012. Options for coastal farmers of Bangladesh adapting to impact of climate change. Intl. Conf. Environment, Agric \& Food Sci., Aug 11-12, 2012, Phuket, Thailand. pp. 17-21

Sattar, S A. 2002. Agriculture in CDSP-II project areas. Vol. 1: Agroecosystems and productive potential of Noakhali coastal chars. Technical Report No. 5. Char Development and Settlement Project-II. 58p.
Sattar, S A and H J W Mutsaers. 2004. Agriculture in southeastern coastal chars of Bangladesh. Vol. 1: Experiences and Guidelines.Technical Report No. 12. Char Development and Settlement Project-II. 98p.

Shah, A L, A Rashid and S Rahman. 2004. Integrated fertilizer management in saline soils. Soil Science Div., Bangladesh Rice Research Institute, Gazipur, Bangladesh. 